\title{
Mitigation of Cu(II) from Aqueous Solution by Using Sandal Santalum Album Distillation Biomass
}

\author{
Qadeer Ul Hassana , Adil Munira,*, Asad Bashira, Farhan Alia , Rana Muhammad Shahid ${ }^{\mathrm{b}}$
}

a Department of chemistry and Biochemistry, University of Agriculture Faisalabad, Faisalabad, Pakistan

b Department of chemistry, Minhaj University Lahore, Lahore, Pakistan

\begin{tabular}{|c|c|}
\hline ART I C LE I N F O & A B S T R A C T \\
\hline $\begin{array}{l}\text { Received: } 14 \text { September } 2019 \\
\text { Revised: } 10 \text { December } 2019 \\
\text { Accepted: } 25 \text { December } 2019 \\
\text { Available online: } 30 \text { December } 2019 \\
\text { K E Y W O R D S } \\
\text { Sandal Santalum album } \\
\text { Biosorption } \\
\text { Mitigation } \\
\text { Frendlich isotherm }\end{array}$ & $\begin{array}{l}\text { In this study, mitigation of } \mathrm{Cu}(\mathrm{II}) \text { from aqueous solutions was evaluated } \\
\text { using the sandal Santalum Album as biosorbent. The removal capacity of } \\
\text { the } \mathrm{Cu}(\mathrm{II}) \text { was studied in batch experiments including such as initial } \\
\text { metal concentration }(25-400 \mathrm{mg} / \mathrm{L}) \text {, biosorbent dose }(0.05-0.2 \mathrm{~g}) \text {, effects } \\
\text { of contact time }(0-1440 \mathrm{~min}) \text {, kinetics and pre-treatment of the } \\
\text { biosorbent. The maximum removal of } \mathrm{Cu}(\mathrm{II}) \text { was obtained at the } \\
\text { optimum pH of } 5 \text {. The maximum equilibrium uptake for } \mathrm{Cu}(\mathrm{II}) \text { was } \\
\mathrm{Ba}(\mathrm{OH})_{2}-\mathrm{SA}\left(248.8 \mathrm{mg} / \mathrm{g}^{-1}\right) \text { at } 400 \mathrm{ppm} \text {. Kinetics studies explained that, } \\
\text { mitigation of the } \mathrm{Cu}(\mathrm{II}) \text { was very fast from } 0 \text { to } 120 \text { min and achieved } \\
\text { equilibrium at } 240 \mathrm{~min} \text {. The equilibrium was well explained by Frendlich } \\
\text { isotherm. Kinetics was well fitted to pseudo second order equation with } \\
\text { high } \mathrm{R}^{2} \text { values. }\end{array}$ \\
\hline
\end{tabular}

\section{GRA P H I C A L A B S TRACT}

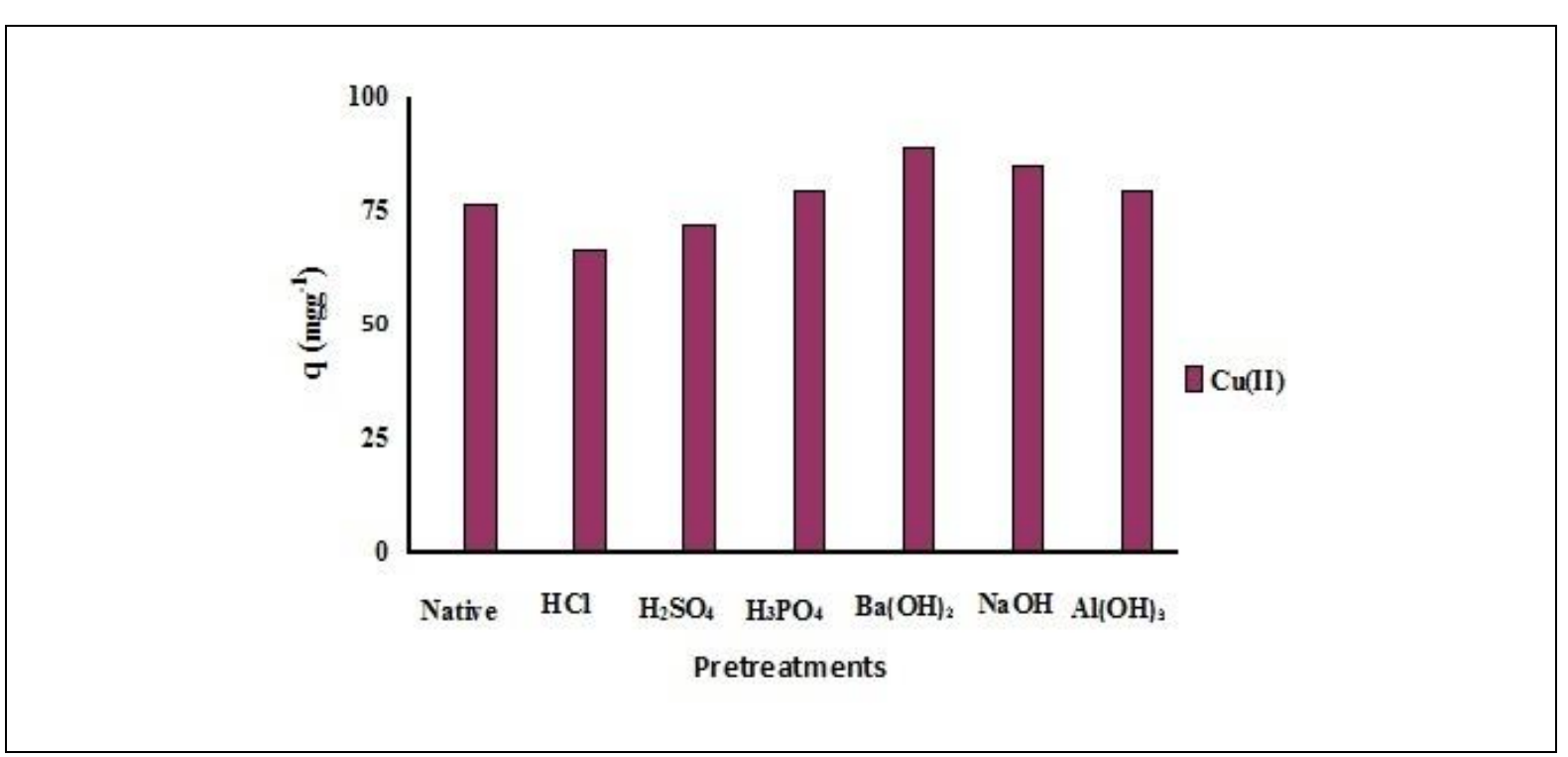

*Corresponding author's E-mail address: warraich_adil@yahoo.com 


\section{Introduction}

Water is the very basic part of our lives. The human body consists of approximately $64 \%$ water that requires $2-3 \mathrm{~L}$ of drinking water daily to maintain a healthy balance within the body (during normal conditions). With the technology advancement, the natural environment suffers from the negative effects of pollution. Pollution of environment multiplies with industrialization, mining, and agriculture. The water contaminated by toxic organic chemicals and heavy metals from the micro-polluted wastewater discharges has become a universal ecological problem. Water pollution is the contamination of water bodies (such as lakes, rivers, oceans, and ground water). Water pollution affects plants and organisms living in water. Water pollution occurs when pollutants are discharged directly or indirectly into the water bodies without sufficient treatment to remove harmful compounds. Thus, heavy metal pollution is measured as a main problem of increasing extent. Heavy metals are relentless and consequently it would be very hard to eradicate naturally from the environment. Almost all the heavy metals are highly poisonous, non-biodegradable, and readily accumulate to toxic levels [1]. There are many types of water pollution as industrial is one of them type of pollution. Different statistics optimised that about 5 million people died due to lack of pure water [2]. The effluents in industries usually contain a significant amount of copper, which spreads into the environment through soils and water streams and may accumulate along the food chain, resulting in a high risk to human health. Industries such as mining, brace, and electroplating release aqueous effluents containing reasonably high level of heavy metals such as silver, cadmium, copper, cobalt, chromium, zinc, iron, and lead [3]. Heavy metals are engaged into the body through breathing, ingestion and skin adsorption. Many of the heavy metals are enormously detrimental to humans, animals and plants because of their accumulation in the body [4]. Due to development of technical and industrial activities, the release of $\mathrm{Cu}$ (II) metal ions to the water bodies are going up [5].

Copper is a chemical element with the symbol $\mathrm{Cu}$ (from Latin: cuprum) and atomic number 29. It is a ductile metal with very high thermal and electrical conductivity. It is used as a conductor of heat and electricity, a building material, and a constituent of various metal alloys. $\mathrm{Cu}$ is required for various biological processes, whereas it is potentially poisonous. $\mathrm{Cu}(\mathrm{II})$ is broadly used in many industries including metal cleaning and plating. With discharges from various industries such as mining, metal plating, dyes and smelting, copper can be released into the natural environment. $\mathrm{Cu}(\mathrm{II})$ with low concentration was reported to be able to recover the performance of biological treatment. Nevertheless, ecological impacts might be observed when $\mathrm{Cu}$ (II) concentrations exceed $0.2 \mathrm{mg} / \mathrm{L} . \quad \mathrm{Cu}(\mathrm{II})$ accumulates along the food chain, consequential in a high risk to human health, as high concentrations of copper will cause stomach upset and ulcer, mental retardance, liver and brain damage [6]. According to the Safe Drinking Water Act, the permissible limit of copper in drinking water is $1.3 \mathrm{mg} / \mathrm{L}$ [7]. Exceeding the threshold concentration of $0.002 \mathrm{~g} / \mathrm{L}$, they become toxic to human beings and animals [8]. $\mathrm{Cu}$ (II) at high concentration is toxic to living organisms and particularly to fish. Parkinsonism is caused by the presence of the overindulgence of $\mathrm{Cu}(\mathrm{II})$ in human body. Research is consequently significant to fully be aware of systems and technologies for their removal. The increasing level of these toxic heavy metals in aqueous medium is encouraging the scientists to develop new and alternative technologies to eradicate trace metals from polluted waters [9]. Conventional 
methods for mitigation of heavy metals, including chemical precipitation and filtration, redox reactions, electrochemical treatments, reverse osmosis, ion exchange, adsorption and evaporation, are generally luxurious or insufficient for treating highly diluted solutions [10]. Although, these techniques have certain disadvantages such as inequitable removal, elevated reagent and energy needs, production of toxic slush or other waste stuff involve dumping [11]. Among all these techniques, biosorption is to be emerged as low cast, environment friendly, and effective method. Biosorption is defined as the capacity of organic materials to collect the heavy metals from polluted water through metabolically mediated or physico-chemical pathway of uptake. Various functional groups such as carboxyl, amines, carbonyl, sulphontes, and phosphonates are involved in this process. The main advantages of the biosorption over the conventional separation methods include low cost, high effectiveness, minimum amount of chemical or biological sludge, restoration of biosorbent, no further nutrient requirement, and maximum chances of metal removal [12].

Santalum album (Sandalwood) is the name of a class of fragrant woods. The wood is heavy and yellow in colour as well as fine-grained and unlike many other aromatic woods it retains its fragrance for decades. The main chemical components of sandal wood are santalol, santyl acetate and santalene. The essential oil contains high amounts of alphaand beta-santalol. Sandalwood has become a popular wood to use for Tasbeeh prayer beads and has been so since the time of Hazrat Muhammad (Peace Be Upon Him). The sandalwood fragrance is very distinctive and is used in countless applications. Sandalwood has been valued and treasured for many years for its fragrance, carving, medical and religious qualities. These small molecules possess antibacterial and sedative properties. Sandalwood oil was used traditionally to treat skin diseases, acne, dysentery, gonorrhoea and a number of other conditions. It affects the circulatory, digestive, respiratory and nervous systems. It relieves fever, thirst, burning sensation and stops sweating. It is good for fever or over exposure to the sun. The oil or paste is useful for most infectious sores and ulcers if applied externally. The essential oil of sandal was extracted in Rose Lab University of Agriculture Faisalabad. The remaining was discarded as a waste biomass. The new material was chosen as biosorbent in this study as it was natural, easily available and thus a low cost biomass for dissolved metal ions. In the present work Sandal Santalum album as a biosorbent material was used to investigate the possible removal of $\mathrm{Cu}(\mathrm{II})$ ions from aqueous solutions. This study included an assessment of the effects of a range of process parameters i.e. metal ion concentration, contact time and biosorbent dose. The kinetic and equilibrium isotherm models associated with the method were also optimized [13]. The present study was undertaken with following objectives:

1. To investigate the efficiency of sandal waste biomass (Santalum album) as biosorbent.

2 . To optimize the effect of various operational parameters like initial metal concentration, biosorbent dose, pretreatment (acid and base) and contact time.

3. To study the mechanism of $\mathrm{Cu}(\mathrm{II})$ biosorption using kinetic and isotherm modelling.

\section{Experimental}

\section{Material and methods}

\section{Reagents}

All the chemicals used in this study were of analytical grade purchased from Fluka chemicals including standard $\mathrm{Cu}$ solutions (1000 ppm) of atomic absorption spectrophotometer. The chemicals used in this process included Hydrochloric acid $(\mathrm{HCl})$, 
Sulphuric Acid $\left(\mathrm{H}_{2} \mathrm{SO}_{4}\right)$, Phosphoric Acid $\left(\mathrm{H}_{3} \mathrm{PO}_{4}\right)$, Sodium Hydroxide $(\mathrm{NaOH})$, Barium Hydroxide $\left\{\mathrm{Ba}(\mathrm{OH})_{2}\right\}$, Aluminium Hydroxide $\left\{\mathrm{Al}(\mathrm{OH})_{3}\right\}$ and Copper Sulphate $\left(\mathrm{CuSO}_{4} \cdot 5 \mathrm{H}_{2} \mathrm{O}\right)$ for stock solution $2.51 \mathrm{~g}$ was dissolved in distilled water in beakers and then diluted to $1000 \mathrm{~mL}$ in volumetric flask. The solutions were stored in airtight plastic bottles. Glassware and polypropylene flasks were immersed overnight in $10 \%$ (v/v) Nitric Acid $\left(\mathrm{HNO}_{3}\right)$ and rinsed several times with distil water.

\section{Preparation of biomass}

The essential oil of sandal was extracted in Rose Lab University of Agriculture Faisalabad. The remaining was discarded as a waste biomass. Then, the waste biomass was distilled from Rose lab of Horticulture Sciences, University of Agriculture, Faisalabad, Pakistan. The washed biomass was dried in electronic oven at $60{ }^{\circ} \mathrm{C}$ for $72 \mathrm{~h}$ and then kept in desicator to cool the biosorbent in the absence of air for 4 hour and then grinded. The biomass was sieved through Octagon siever (OCT-DIGITAL 452701 ) to obtain adsorbent with homogenous known particle size. The size of biosorbent particles with fraction size of $0.25 \mathrm{~mm}$ was selected because the particles homogenises easily and carried out sorption smoothly with this particles size. The sieved sorbents were finally preserved separately in air tight containers at standard temperature and pressure for further experiments.

\section{Preparation of pretreatments}

The uptake of $\mathrm{Cu}(\mathrm{II})$ was tested with chemical pretreatments using sandal Santalum album(SA) as a waste biomass.

\section{Acidic pretreatments}

In case of acidic treatments, $5 \mathrm{~g}$ of finely divided biomass was soaked in $100 \mathrm{~mL}$ of 0.1 $\mathrm{N}$ solutions of $\mathrm{HCl}-\mathrm{SA}, \mathrm{H}_{2} \mathrm{SO}_{4}-\mathrm{SA}$ and $\mathrm{H}_{3} \mathrm{PO}_{4}$-SA in separate conical flasks. Flasks were incubated at $100 \mathrm{rpm}$ and $30^{\circ} \mathrm{C}$ for $24 \mathrm{~h}$ [14]. Then suspensions were extensively washed with deionized distilled water (DDW) and filtered. Finally the resulting biomass was oven dried for $48 \mathrm{~h}$ to constant weight. The dried samples were grounded with pestle and mortar and passed through Octagon Siever to maintain the size of the sandal Santalum album biomass as $0.25 \mathrm{~mm}$.

\section{Basic pretreatments}

In case of basic treatments, $5 \mathrm{~g}$ of finely divided biomass was soaked in $100 \mathrm{~mL}$ of 0.1 $\mathrm{N}$ solutions of $\mathrm{NaOH}-\mathrm{SA}, \mathrm{Ba}(\mathrm{OH})_{2}$-SA and $\mathrm{Al}(\mathrm{OH})_{3}$-SA in separate conical flasks. Flasks were incubated at $100 \mathrm{rpm}$ and $30^{\circ} \mathrm{C}$ for 24 hour [14]. Then suspensions were extensively washed with deionized distilled water (DDW) and then filtered. Finally the biomass was dried at $30^{\circ} \mathrm{C}$ for $48 \mathrm{~h}$ to constant weight. The dried samples were grounded with pestle and mortar and passed through Octagon Siever to maintain the size of the sandal Santalum album biomass as $0.25 \mathrm{~mm}$. Perkin-Elmer Analyst $\quad 300$ atomic absorption spectrophotometer equipped with an air acetylene burner. It was handled by computer to evaluate the amount of $\mathrm{Cu}$ (II) in aqueous solution before and after the equilibrium achieved.

\section{Batch biosorption studies}

In all sets of experiments, fixed volume of $\mathrm{Cu}(\mathrm{II})$ solutions $(100 \mathrm{~mL})$ was thoroughly mixed with desired biosorbent dose $(0.1 \mathrm{~g})$ at $30{ }^{\circ} \mathrm{C}$ and $120 \mathrm{rpm}$ up to $24 \mathrm{~h}$. To check the influence of initial metal concentration, biosorbent dose and contact time on sorption of $\mathrm{Cu}$ (II) by sandal Sanatlum album waste biomass different conditions of initial metal concentration $(25,50,100,200$, and 400 ppm), contact time $(0,30,60,120,240,480$, and $1440 \mathrm{~min}$ ) and biosorbent dose (0.5, 0.1, and $0.2 \mathrm{~g}$ ) were selected to study the 
biosorption experiments. For adjusting the $\mathrm{pH}$ of the medium, $0.1 \mathrm{~N}$ solutions of $\mathrm{NaOH}$ and HC1 were used. The flasks were covered with aluminium foil and placed on a rotating shaker (PA 250/25.H) with constant rate of $120 \mathrm{rpm}$. After $24 \mathrm{~h}$ samples were filtered with filter paper and stored in air tight sample bottles. Biosorption capacities were calculated for each concentration by the obtained readings of Atomic absorption spectrophotometer (AAS).

Calculation of $\mathrm{Cu}(\mathrm{II})$ up takes (adsorption capacity)

Uptake of $\mathrm{Cu}(\mathrm{II})$ ion was calculated from a mass balance equation 1 .

$q=(C i-C e) V / 1000 w$

$\mathrm{q}=\mathrm{Cu}(\mathrm{II})$ uptake capacity $(\mathrm{mg} \mathrm{Cu}(\mathrm{II}) / \mathrm{g}$ Santalum album biomass)

$\mathrm{Ci}=$ Initial $\mathrm{Cu}$ (II) concentration in solution, before the adsorption test (mg/L).

$\mathrm{Ce}=$ Final $\mathrm{Cu}(\mathrm{II})$ concentration in solution (mg/L)

$\mathrm{V}=$ Solution volume $(\mathrm{ml})$

All data represented the mean of three independent experiments. All results were discussed by using mean \pm SD (Standard Deviation). All statistical analysis done by using Microsoft Excel 2003, version office Xp.

\section{Equilibrium modelling}

Adsorption isotherms of $\mathrm{Cu}(\mathrm{II})$ concentration from 25 to $400 \mathrm{mg} / \mathrm{L}$ with a predetermined adsorbent doses $(0.1 \mathrm{~g} / 100$ $\mathrm{mL}$ ) at the $\mathrm{pH}$ of 5 was estimated. Freundlich and Langmuir adsorption isotherms were applied to depict the equilibrium interaction between the sorbent and sorbate in solution. Sorption equilibrium was achieved when the concentration of the sorbate in the bulk solution was dynamic balance with that of the interface [15]. Different concentration of $\mathrm{Cu}(\mathrm{II})$ solutions were applied to get equilibrium data. There are different models which was applicable to this sorption process.

\section{Freundlich isotherm model}

The Freundlich isotherm is formerly empirical in nature but was afterwards interpreted as sorption to various surface or surface supporting sites of diverse affinities. It is assumed that the stronger binding sites are occupied first and the binding strength decreases with the increasing degree of site occupation [16]. The Freundlich parameters can be determined from a linearized form of equation 2 as given below:

$\log q e=1 / n \log C e+\log K$

Where qe is the metal ion adsorbed $(\mathrm{mg} / \mathrm{g})$. Ce is the equilibrium concentration of metal ion solution $\mathrm{mg} / \mathrm{L}, \mathrm{K}$ and $1 / \mathrm{n}$ are constant. The constant $\mathrm{K}$ and $1 / \mathrm{n}$ were determined by linear regression from the plot of $\log \mathrm{q}$ against $\log \mathrm{Ce}$ [17].

\section{Langmuir isotherm model}

The Langmuir isotherm speculation assumes monolayer exposure of adsorbate over a uniform adsorbent surface. Langmuir isotherm can be regarded as by a plateau graphically [18]. A saturation point reaches at equilibrium where no advance adsorption occurs. Adsorption is supposed to occur at specific uniform sites within the adsorbent. Once a sorbate molecule occupies a site, no more adsorption takes place at that site [19]. The Langmuir parameters can be evaluated from a linearized form of equation 3 represented by,

$\mathrm{Ce} / \mathrm{qe}=1 / \mathrm{XmKl}+\mathrm{Ce} / \mathrm{Xm}$

Where qe is the metal ion sorbed ( $\mathrm{mg} / \mathrm{g}$ ), Ce the equilibrium concentration of metal ion solution, $\mathrm{Xm}$ and $\mathrm{Kl}$ are the Langmuir constants [19]. 


\section{Kinetic modelling}

The kinetics of $\mathrm{Cu}(\mathrm{II})$ sorption onto native, acidically and basically treated Santalum album waste biomass was optimized by using Morris-Weber Lagergren pseudo-first-order and pseudo-second order equations. In order to investigate the kinetics of biosorption, two kinetic models, Lagergren's pseudo-firstorder and pseudo-second-order were employed [20]. The Pseudo-first-order Lagergren model for solid/liquid systems of adsorption is explained in the form of equation 4 .

$\log \left(q e_{-} q\right)=\log q e_{-} k 1 t / 2.303$

Where qe and q (mg/g) are the amounts of copper adsorbed on the biomass at equilibrium and at any time $\mathrm{t}$, in $\mathrm{mg} / \mathrm{g}$, respectively. $\mathrm{k} 1\left(\mathrm{~min}^{-1}\right)$ is the rate constant of pseudo-first-order biosorption. The model is based on the assumption that the rate is proportional to the number of unoccupied sites. The slopes and intercepts of plot of log (qe _ q) versus t were used to calculate the first-order rate constant $\mathrm{k} 1$ and equilibrium adsorption capacity qe. The adsorption kinetics data were further analyzed using the pseudo-second-order kinetic model. The model was based on the assumption that the rate of the sorption is proportional to the square of the number of unoccupied sites. It is expressed as in the equation 5 .

$\mathrm{t} / \mathrm{q}=1 / \mathrm{k} 2 \mathrm{qe} 2+\mathrm{t} / \mathrm{qe}$

Where $\mathrm{k} 2$ is the equilibrium rate constant of pseudo-second-order adsorption (gm/g-1/ $\mathrm{min}^{-1}$ ). The slopes and intercepts of plots $t / q$ versus $t$ were used to calculate the pseudo-second-order rate constants $\mathrm{k} 2$ and qe.

\section{Result and discussion}

Effects of pretreatments
To estimate the effect of pretreatments on the dried biomass of sandal Santalum album $100 \mathrm{mg} / \mathrm{L}$ of $\mathrm{Cu}(\mathrm{II})$, the solution was shaken at $120 \mathrm{rpm}$ with $0.1 \mathrm{~g}$ of native and pretreated biomass of sandal Santalum album. Particle size of the biomass was $0.25 \mathrm{~mm}$ at the $\mathrm{pH}$ of 5 for $\mathrm{Cu}(\mathrm{II})$. Removal capacity of the pretreated biomass was high as compared to native biomass. The effect of pretreatments on dried biomass of sandal Santalum album for $\mathrm{Cu}(\mathrm{II})$ removal from aqueous solution is shown in the Figure 1 . The $\mathrm{q}\left(\mathrm{mg} / \mathrm{g}^{-1}\right)$ values of $\mathrm{Cu}$ (II) for native and pretreated biomass of sandal Santalum album were in the following order respectively.

$\mathrm{Ba}(\mathrm{OH})_{2}-\mathrm{SA}(87.5)>\mathrm{NaOH}-\mathrm{SA}(83.4)>\mathrm{Al}(\mathrm{OH})_{3}-$ $\mathrm{SA}(79.7)>\mathrm{H}_{3} \mathrm{PO}_{4}-\mathrm{SA}(76.40)>\mathrm{H}_{2} \mathrm{SO}_{4}-\mathrm{SA}(75.90)$ $>$ native(73.60) $>\mathrm{HCl}-\mathrm{SA}(69.0)$

In pretreatment of $\mathrm{Cu}(\mathrm{II}), \mathrm{Ba}(\mathrm{OH})_{2}-\mathrm{SA}$ pretreated sandal Santalum album showed maximum biosorption as compared to $\mathrm{HCl}-\mathrm{SA}$ pretreated. $\mathrm{Ba}(\mathrm{OH})_{2}$-SA could rupture the biomass cells which could release polymers such as polysaccharides that have a high affinity towards certain metal ions.

Metal combining capacity of the biomass can be influenced by pretreating the biomass with diverse reagents which may increase or decrease the amount of the metal sorbed. Therefore the dead biomass was treated with acids and bases [21]. An increase in biosorption of $\mathrm{Cu}(\mathrm{II})$ as a result of pretreatment could be due to an exposure of active metal binding. Huang and Huang stated that the increase in metal biosorption after pretreating the biomass could be due to the removal of surface impurities and to the exposure of available binding sites for metal biosorption.

\section{Effects of initial metal concentration}

The experiments were performed by using different concentrations of $\mathrm{Cu}(\mathrm{II})$ solution under the optimum $\mathrm{pH}$ values and contact 
time. The effect of initial single metal ion concentration was investigated in the range of
25-400 mg/ $/ \mathrm{L}^{-1}$. The results have been depicted in Figure 2.

Figure 1. Effect of pretreatments on $\mathrm{Cu}(\mathrm{II})$ Biosorption using sandal Santalum album biomass

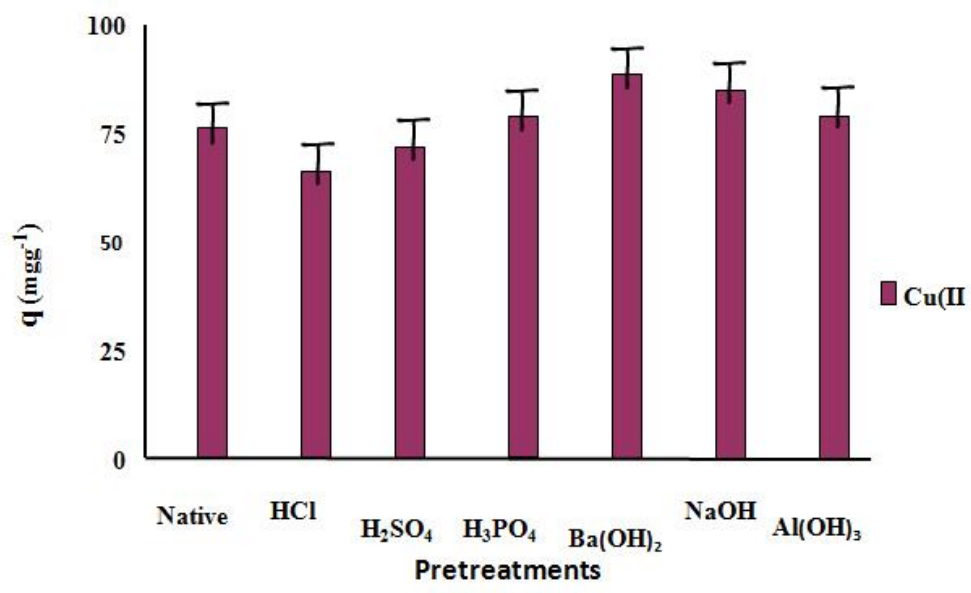

Figure 2. Effect of initial metal concentration

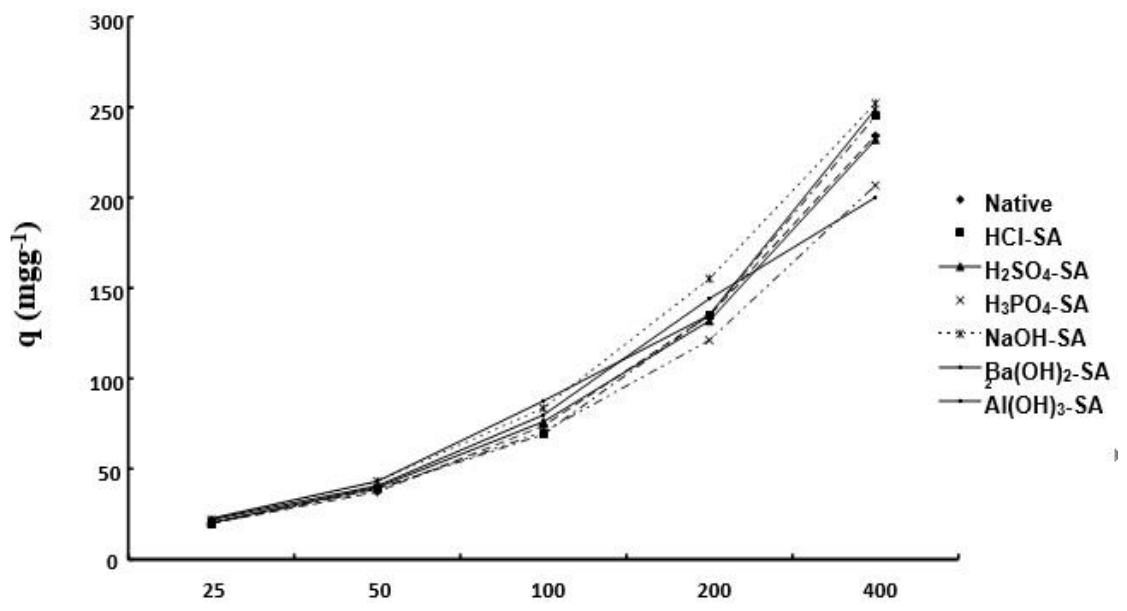

The $\mathrm{Cu}(\mathrm{II})$ biosorption capacity of the biomass increased with increasing of the initial concentration of metal ion. The maximum equilibrium uptake for $\mathrm{Cu}$ (II) was $\mathrm{Ba}(\mathrm{OH})_{2}$-SA $\left(248.8 \mathrm{mg} / \mathrm{g}^{-1}\right)$ at $400 \mathrm{ppm}$. The rate of adsorption is a function of the initial concentration of metal ions. At high metal ion concentration, the number of metal ions sorbed more than at low metal concentration, where more binding sites were frequently available for contact. So the increase in initial concentration of $\mathrm{Cu}(\mathrm{II})$ will enhance the adsorption process [22]. On increasing metal ion concentration \% removal decreased due to declining loading ability of biomass [23].
The increase in sorption capacity may be explained by the fact that at low concentrations, the available metal occupies adsorption sites more quickly. The decrease in percentage removal was explained by the fact that at lower concentrations, almost all the ions were adsorbed very quickly and further increase in the initial metal ion concentration led to saturation of biomass surface [24].

Initial metal concentration $\left(\mathrm{mg} \mathrm{L}^{-1}\right)$

\section{Effect of biosorbent dose}

This experiment was performed to observe the influence of the amounts of biosorbent on 
the biosorption of $\mathrm{Cu}(\mathrm{II})$, the experiments were evaluated with the particle size of the biomass was $0.25 \mathrm{~mm}$ at the $\mathrm{pH}$ of 5 for $\mathrm{Cu}(\mathrm{II})$, while all the parameters kept constant and only used different amount of biosorbent. Biosorbent dose seems to have a great manipulate on biosorption processes. Figure 3 represent the effect of biosorbent dose on the sorption capacity of sandal Santalum album biomass for removal of $\mathrm{Cu}$ (II) from aqueous solution. The $\mathrm{q}\left(\mathrm{mg} / \mathrm{g}^{-1}\right)$ values of $\mathrm{Cu}$ (II) for native and pretreated biomass of Santalum album were in the following range:

$\mathrm{NaOH}-\mathrm{SA}(87.9-82.7)>\mathrm{H}_{3} \mathrm{PO}_{4}-\mathrm{SA}(87.2-$ 61.4) $>\mathrm{Al}(\mathrm{OH})_{3}-\mathrm{SA}(85.7-64)>\mathrm{H}_{2} \mathrm{SO}_{4}-\mathrm{SA}(84.80-$ $61)>\mathrm{Ba}(\mathrm{OH})_{2}-\mathrm{SA}(83.5-78.8)>$ native $(80.7-$ 70.8) $>\mathrm{HCl}-\mathrm{SA}(80.5-75.1)$

Decrease in sorption capacity of the biosorbent with the increase in sorbent dose was due to the increase surface area [25]. The increase in sorbent dose at constant dye concentration and volume may lead to saturation sites [26]. Results of the biomass dose revealed that the amount of metal bound per $g$ of biomass decreased as the biomass concentration increased. It is shown by the results that at lowest dosage of biomass resulted in highest removal of metal. The metal uptake capacity and percentage of the metal removal are of equally importance in sorption experiments as both usually take part in deciding the sorption performance of a given biosorbent [22].

\section{Effect of contact time}

Contact time was one of the significant factors for an efficient wastewater treatment [15]. The experiments were conducted to determine the time required for sandal Santalum album to bind the $\mathrm{Cu}(\mathrm{II})$. Effect of contact time on chemically pretreated sandal Santalum album biomass was studied at optimum conditions i.e., at optimum pH 5 for
$\mathrm{Cu}(\mathrm{II}), 0.25 \mathrm{~mm}$ size, temperature $30{ }^{\circ} \mathrm{C}$ and $0.1 \mathrm{~g}$ of biomass at $120 \mathrm{rpm}$ shaking speed.

In case of $\mathrm{Cu}(\mathrm{II})$ biosorption capacity increase from 53.1 to $76.6 \mathrm{mg} / \mathrm{g}^{-1}$ for native, 60 to 75.1 for $\mathrm{HCl}-\mathrm{SA}, 60.4$ to $75.9 \mathrm{mg} / \mathrm{g}^{-1}$ for $\mathrm{H}_{2} \mathrm{SO}_{4}-\mathrm{SA}, 61.8$ to $76.4 \mathrm{mg} / \mathrm{g}^{-1}$ for $\mathrm{H}_{3} \mathrm{PO}_{4}-\mathrm{SA}, 76$ to $85.4 \mathrm{mg} / \mathrm{g}^{-1}$ for $\mathrm{NaOH}-\mathrm{SA}, 77.5$ to $83.5 \mathrm{mg} / \mathrm{g}^{-1}$ for $\mathrm{Ba}(\mathrm{OH})_{2}-\mathrm{SA}$ and 69 to $79.5 \mathrm{mg} / \mathrm{g}^{-1}$ for $\mathrm{Al}(\mathrm{OH})_{3}-\mathrm{SA}$ at time 0-1440 min (as shown in Figure 4). Information on the kinetics of metal uptake is required for selection of optimum conditions for full-scale batch metal removal process. A kinetic study with different time intervals with fixed metal and biosorbent concentration was performed. The percent adsorption increases with contact time until the equilibrium was attained. Studies revealed that the majority of metal ions were removed within the first $60 \mathrm{~min}$. The equilibrium state was attained at 120 min. Further increase in contact time did not show an increase in biosorption. Lower adsorption rate in the later stages was due to the difficulty faced by metals ions to occupy the remaining vacant surface sites because of forces between the solute molecules of the solid and bulk phase [25].

\section{Equilibrium models}

To explain the distribution of the solute in the solid phase and liquid phase at equilibrium condition, it is essential to express the amount of solute absorbed per unit weight of sorbent, (q) as a function of the residual equilibrium concentration $\mathrm{C}_{e}$ of solute remaining in solution. The expression of this affiliation is termed as an adsorption isotherm. The equation parameters of these equilibrium models frequently give some insight into the adsorption mechanism, the surface properties and affinity of the adsorbent. In this work, the Langmuir and Freundlich isotherm model were tested. Langmuir and Freundlich isotherm are often used to fit experimental statistics [26]. 
Figure 3. Effect of biosorbent dose on $\mathrm{Cu}(\mathrm{II})$ uptake using sandal Santalum album biomass

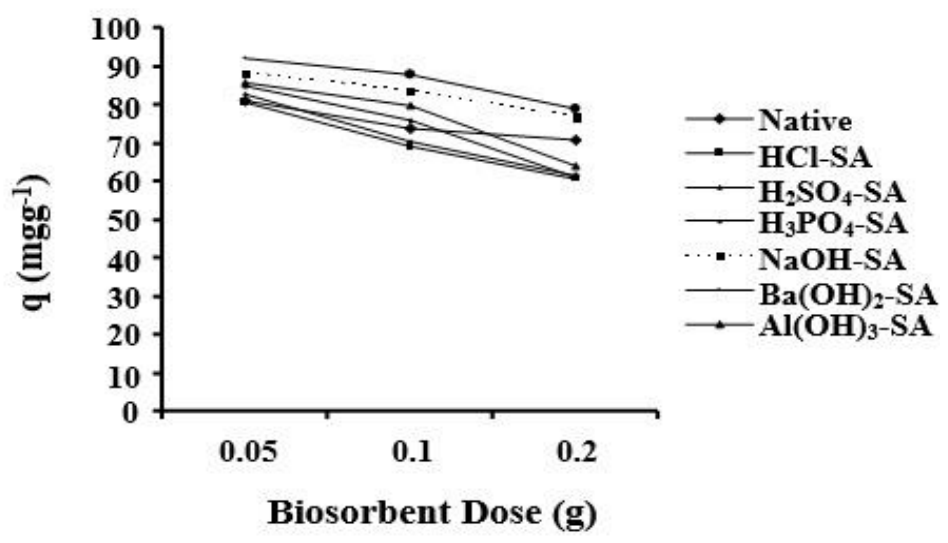

Figure 4. Effect of contact time on $\mathrm{Cu}(\mathrm{II})$ uptake using sandal Santalum album biomass

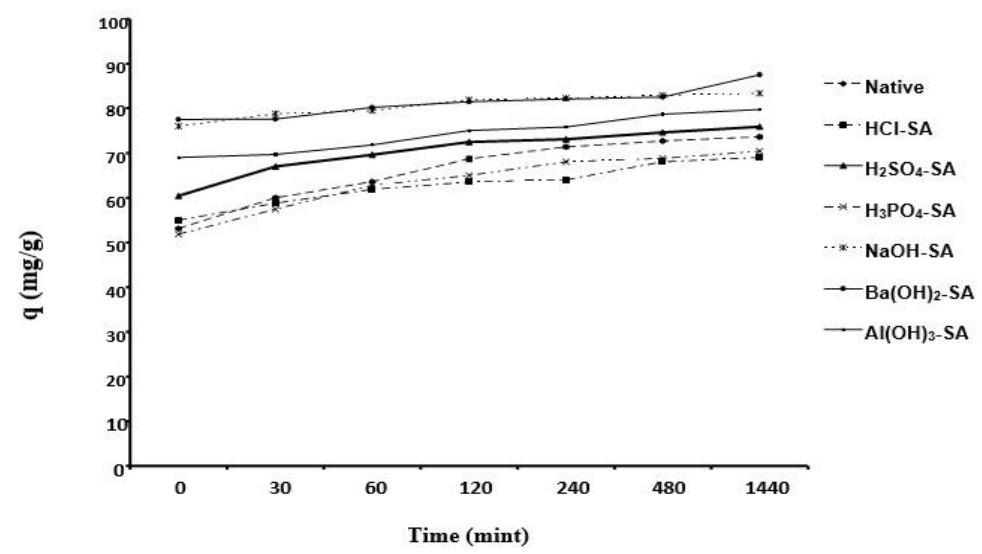

Figure 5. Freundlich adsorption isotherm for $\mathrm{Cu}(\mathrm{II})$ biosorption by native and pretreated sandal Santalum album biomass

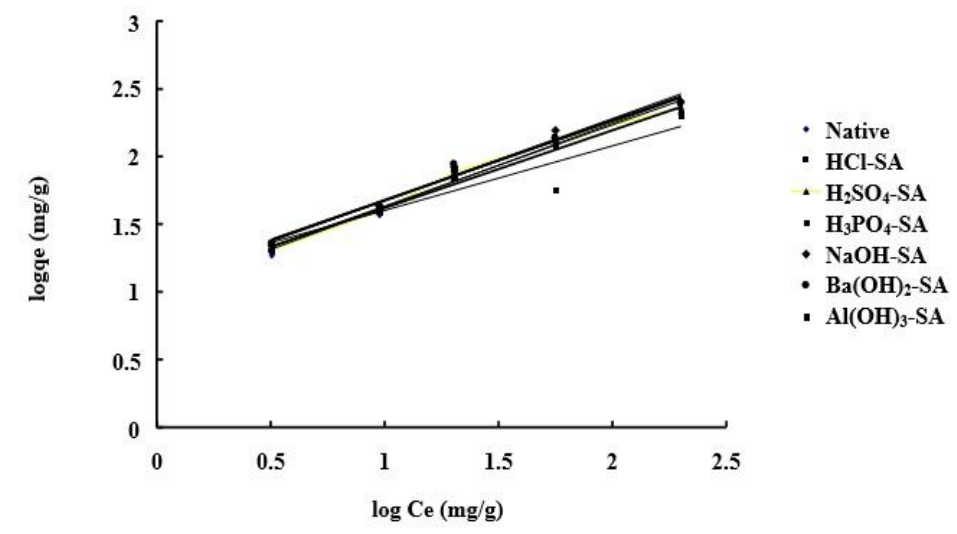

In Freundlich isotherm model the values of $\mathrm{R}^{2}$ are greater for $\mathrm{NaOH}-\mathrm{SA}, \mathrm{H}_{3} \mathrm{PO}_{4}$-SA, native, $\mathrm{H}_{2} \mathrm{SO}_{4}$-SA, HCl-SA, $\mathrm{Al}(\mathrm{OH})_{3}$-SA and $\mathrm{Ba}(\mathrm{OH})_{2}$-SA as compared to Langmuir isotherm model for $\mathrm{Cu}(\mathrm{II})$. So Freundlich isotherm model had a better fitting model as compared to Langmuir isotherm model for $\mathrm{Cu}$ (II). This was as a result of higher correlation coefficient exhibited by Freundlich. The $q_{\max }$ was the maximum value of $q_{\mathrm{e}}$, which was important to identify which biosorbent has the highest metal uptake capacity and as such useful in scale up considerations. The $\mathrm{R}^{2}$ and $q_{\max }$ values for $\mathrm{Cu}$ (II) suggested that the Freundlich isotherm described the sorption well. The data conversion to Freundlich model yielded straight line for metal. The value of $\mathrm{R}^{2}$ regarded as measure of the goodness of fit of experimental data on the isotherm models. Therefore our data is not applicable for Langmuir isotherm. 
Kinetic model

A comparison between the pseudo-firstorder and pseudo-second-order kinetic models is shown in the Figures 7 and 8 . The second-order rate model has received considerable attention as a tool for quantitatively predicting the uptake of metals from aqueous solutions. In addition to high value of coefficient of determination $\left(R^{2}\right)$, a close agreement between experimental and estimated qe values suggests that sorption process followed second order mechanism. Values for pseudo second order are near to experimental values, but not for pseudo first order. Values for pseudo second order are near to the experimental values, but not for pseudo first order. In this model, the ratelimiting step is a biosorption mechanism involving chemisorptions, where metal removal from solution is due to purely physico-chemical interactions between biomass and metal solution.
Figure 6. Langmuir adsorption isotherm for $\mathrm{Cu}(\mathrm{II})$ biosorption by native and pretreated sandal Santalum album biomass

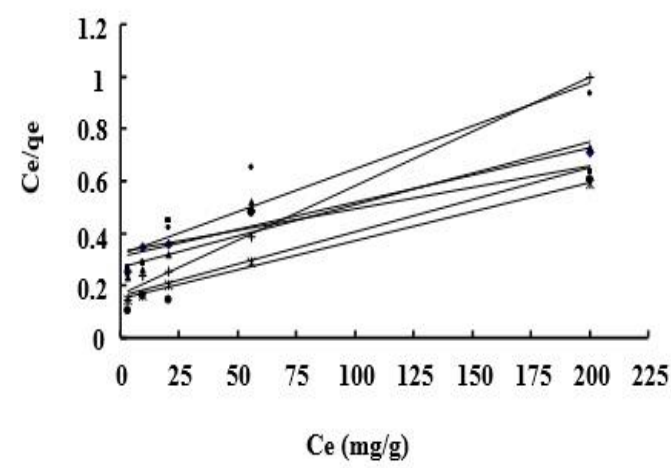

- Native

- HCl-SA

- $\mathrm{H}_{2} \mathrm{SO}_{4}-\mathrm{SA}$

$\cdot \mathrm{H}_{3} \mathrm{PO}_{4}-\mathrm{SA}$

* $\mathrm{NaOH}-\mathrm{SA}$

- $\mathrm{Ba}(\mathrm{OH})_{2}-\mathrm{SA}$

$+\mathrm{Al}(\mathrm{OH})_{3}-\mathrm{SA}$

Figure 7. Pseudo-first-order sorption kinetics plot of $\mathrm{Cu}(\mathrm{II})$ native and pretreated sandal Santalum album biomass

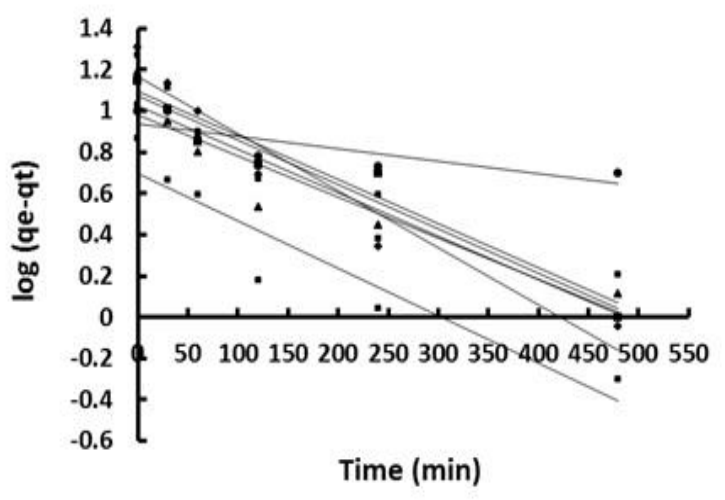

- Native

- $\mathrm{HCl}$

. $\mathrm{H} 2 \mathrm{SO} 4$

- $\mathrm{H} 3 \mathrm{PO} 4$

- $\mathrm{NaOH}$

- $\mathrm{Ba}(\mathrm{OH}) 2$

- $\mathrm{Al}(\mathrm{OH}) 3$

Figure 8. Pseudo-second-order sorption kinetics plot of $\mathrm{Cu}(\mathrm{II})$ native and pretreated sandal Santalum album biomass

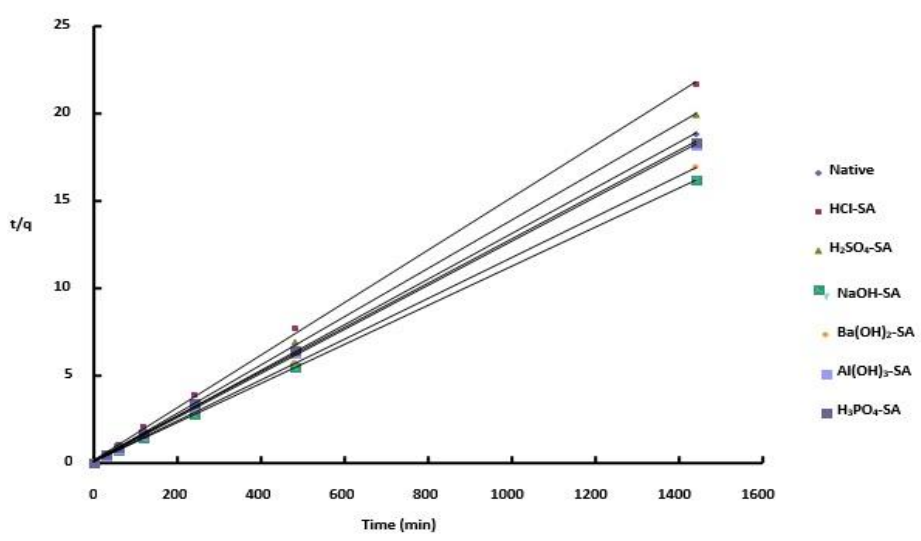




\section{Conclusion}

The native, acidically ( $\mathrm{HCl}-\mathrm{SA}, \mathrm{H}_{2} \mathrm{SO}_{4}$-SA and $\mathrm{H}_{3} \mathrm{PO}_{4}-\mathrm{SA}$ ), basically ( $\mathrm{NaOH}-\mathrm{SA}, \mathrm{Ba}(\mathrm{OH})_{2}-$ $\mathrm{SA}$ and $\left.\mathrm{Al}(\mathrm{OH})_{3}-\mathrm{SA}\right)$ treated waste biomass of the sandal Santalum album was utilized as a potential sorbent for the uptake of $\mathrm{Cu}$ (II) in this research study. The effect of different operational parameters such as pretreatments, initial metal concentrations, biosorbent dose and contact time was analysed from the obtained results. The results indicated that, the waste sandal Santalum album waste biomass was a potential biomaterial to remove the $\mathrm{Cu}$ (II) with a high biosorption capacity for $\mathrm{Cu}$ (II). So, it can be used in future for the treatment of waste water.

\section{Acknowledgement}

The authors wish to thanks Dr. Raziya Nadeem and Dr. Raja Adil Sarfraz Professors of University of Agriculture Faisalabad for carrying out experimental work in Hi-Tech lab of University.

\section{Disclosure statement}

No potential conflict of interest was reported by the authors.

\section{References}

[1] F. Li, J.Q. Jiang, S. Wu, B. Zhang, Chem. Eng. J., 2010, 156, 64-69.

[2] A. Abia, A. Horsfall, M. Jnr, O. Didi, J. Bioresour. Technol., 2003, 90, 345-348.

[3] S. Chakravarty, A. Mohanty, T.N. Sudha, A.K. Upadhyay, J. Konar, J.K. Sircar, A. Madhukar, K.K. Gupta, J. Hazard. Mater., 2010, 173, 502-509.

[4] V.S. Munagapati, V. Yarramuthi, S.K. Nadavala, S.R. Alla, K. Abburi, Chem. Eng. J., 2010, 157, 357-365.

[5] M. Yursever, I.A. Sengil, J. Hazard. Mater., 2009, 163, 58-64.
[6] S. Rathnakumar, R.Y. Sheeja, T. Murugesan, World Academy Sci. Eng. Technol., 2009, 56, 627-635.

[7] M. Areco, M.D.S. Afonso, Colloids Surf. B Biointerfaces., 2010, 81, 620-628.

[8] Y.N. Mata, M.L. Blazquez, A. Ballester, F. Gonzalez, J.A. Munoz, J. Hazard. Mater., 2009, 163, 555-562.

[9] M. Iqbal, G.J. Edyvean, Pakistan J. Botany., 2010, 39, 231-238.

[10] P.D. Johnson, M.A. Watson, J. Brown, I.A. Jefcoat, Waste Manag., 2002, 22, 471-480.

[11] R. Nadeem, T.M. Ansari, A.M. Khalid, J. Hazard. Mater., 2008, 156, 64-73.

[12] H. Lalhruaitluanga, K. Jayaram, M.N.V. Prasad, K.K. Kumar, J. Hazard. Mater., 2010, 175, 311-318.

[13] H. Chen, G. Dai, J. Zhao, A. Zhong, J. Wu, H. Yan, J. Hazard. Mater., 2010, 177, 228236.

[14] N. Fiol, I. Villaescusa, M. Martinez, N. Miralles, J. Poch, J. Serarols, Separat. Purificat. Technol., 2006, 50, 132-140.

[15] T. Fan, Y. Liu, B. Feng, G. Zeng, C. Yang, M. Zhou, H. Zhou, Z. Tan, X. Wang, J. Hazard. Mater., 2008, 160, 655-661.

[16] H. Mubeen, I. Naeem, A. Taskeen, New York Sci. J., 2010, 3, 1-5.

[17] S. Chakravarty, A. Mohanty, T. Nag Sudha, J. Hazard. Mater., 2010, 173, 502-509.

[18] H. Bhatti, R. Khalid, M.A. Hanif, Chem. Eng. J., 2008, 148, 434-443.

[19] Y.N. Mata, M.L. Blazquez, A. Ballester, F. Gonzalez, J.A. Munoz, J. Hazard. Mater., 2008, 158, 316-323.

[20] R. Han, J. Zhang, W. Zou, H. Xiao, J. Shi, H. Liu, J. Hazard. Mater., 2006, 133, 262-268.

[21] D.H. Reddy, K. Seshaiah, A.V. Reddy, M.M. Rao, M.C. Wang, J. Hazard. Mater., 2010, 174, 831-838.

[22] R. Nadeem, M.H. Nasir, M.S. Hanif, Chem. Eng. J., 2009, 150, 40-48.

[23] R. Gong, Y. Ding, H. Liu, Q. Chen, Z. Liu, Chemosphere, 2005, 58, 125-130.

[24] A.E. Ofomaja, A. Ho, Bioresource Technol., 2007, 101, 5868-5876. 
[25] N. Saifuddin, A.Z. Raziah, J. Appl. Sci. Res., 2007, 3, 2091-2099.
[26] M.A. Hanif, R. Nadeem, F. Shaheen, S. Perveen, M.N. Zafar, T. Iqbal, J. Hazard. Mater., 2008, 150, 335-342.

How to cite this manuscript: Qadeer Ul Hassan, Adil Munir, Asad Bashir, Farhan Ali, Rana Muhammad Shahid, Mitigation of $\mathrm{Cu}(\mathrm{II})$ from Aqueous Solution by Using Sandal Santalum Album Distillation Biomass, Adv. J. Chem. A, 2020, 3(4), 473-484. 